B. R. Subba / Our Nature (2003) 1: 1-2

\title{
Molluscan Check List of Ghodaghodi Tal Area, Kailali District
}

\author{
Bharat Raj Subba \\ Department of Zoology, P.G.Campus, Biratnagar \\ Email: brsubba@yahoo.com
}

\begin{abstract}
The paper deals with ten freshwater and one terrestrial mollusc collected from Ghodaghodi Tal area. Among ten freshwater molluscs, nine species belong to six families viz. Planorbidae, Viviparidae, Pilidae, Lymnaedae and Thiaridae of class Gastropoda and one species is of family Amblemidae of the class Bivalvia. The single species of terrestrial mollusc belongs to family Ariophantidae of the class Gastropoda.
\end{abstract}

Keywords: Molluscan diversity, Ghodaghodi Tal, Wetland

\section{Introduction}

Ghodaghodi Tal area lies in Kailali district in far western development region of Nepal at an elevation of $205 \mathrm{~m}$ with $28^{\circ} 41^{\prime}$ $03^{\prime \prime} \mathrm{N}$ latitude and $80^{\circ} 56^{\prime} 43^{\prime \prime} \mathrm{E}$ longitude. The Tal area includes various types of wetlands, rivers and their flood plains, oxbow lakes, swamps, marshes, reservoirs, ponds and paddy fields with a cluster of nine lakes, located in a rectangular area of $5.5 \mathrm{~km}$. by $1.5 \mathrm{~km}$. Climate is tropical monsoonic with ranginng annual rainfall $1630-1705 \mathrm{~mm}$ and drought period remains 5-6 months in a year. Literature on mollusc reveals no report of mollusc from western and far western region of Nepal. However, works (Subba and Ghosh 2000, Subba and Ghosh 2001) on the freshwater and land molluscs of eastern and central Nepal have helped in the survey of mollusc. Recently Subba and Pandey (2002) have described twenty-one species of mollusc of Jhapa district.

\section{Materials and Methods}

Collection of mollusc from Ghodaghodi Tal area was started in Nov $17^{\text {th }}$, 2001 with a view to make a scientific study when wetland inventory work was in its inception. Boat, nylon scoopnet, gloves were used to collect mollusc with the help of local people. The collected samples were brought to Zoology Department of Post Graduate Campus, Biratnagar where identification work was carried out with the help of available literature (Tonapi 1980, Subbarao 1989, Preston 1915) and tallied with samples of molluscs identified and confirmed by Zoological Survey of India (ZSI) Calcutta.

\section{Results and Discussion}

The report includes ten freshwater molluscs belonging to six families and one terrestrial mollusc (Table 1). This work is the first of its kind in western and far western regions of Nepal. However a few reports on mollusc from eastern and central Nepal (Godwin - Austen 1910, Pfeiffer et al. 1999, Subba and Ghosh 2000, Subba and Ghosh 2001, Subba and Pandey 2002) are available.

The most common species of mollusc of Ghodaghodi Tal area were Bellamya bengalensis f. typica, Pila globosa, Indoplanorbis exutus, Lymnaea acuminata $f$. 


\section{B. R. Subba / Our Nature (2003) 1: 1-2}

typica, and Lymnaea acuminata refesseens. But Parreysia caerulea was rarely found. (There were many kinds of bivalves in the past, but indiscriminate killing of them by local people for making one of the delicious ingredients of their food items have resulted in the rapid decline of the population - a statement of local people). As this region suffers from dry weather for 5-6 months every year, no more land mollusc could be included in the present report. Land molluscs were not found in expected numbers in comparison of eastern and central development regions. The latter are having more species of land mollusc (Subba and Ghosh 2001).

Table 1. List of Mollusc of Ghodaghodi Tal area

\begin{tabular}{|l|l|}
\hline Family & Scientific Name \\
\hline Planorbidae & $\begin{array}{l}\text { Indoplanorbis exutus (Deshayes) } \\
\text { Gyraulus convexiusculus (Hutton) } \\
\text { Bellamya bengalensis f. typica (Lamarck) } \\
\text { Bellamya dissimilis }\end{array}$ \\
Pilidae & $\begin{array}{l}\text { Pila globosa (Swainson) } \\
\text { Lymnaedae }\end{array}$ \\
& Lymnaea acuminata f. typica (Lamarck) \\
& Lynmaea acuminata refesseens (Gray) \\
Thiaridae & Lymnaea persica \\
Amblemidae & Thiara tuberculata (Mueller, 1774) \\
Ariophantidae & Parreysia caerulea (Lea, 1831) \\
\hline
\end{tabular}

\section{Acknowledgements}

I am grateful to IUCN for providing me opportunity to carry out wetland inventory work of Ghodaghodi Tal area. My special thanks are due to Dr. Mohan Siwakoti and Mr. Yam Bahadur Bam who helped me to get wetland inventory work. I would like to thank Mr. Kul Prasad Limbu Asst. Lecturer in Zoology, Post Graduate Campus Biratnagar and Mr. Manindra Thebe of Itahari, without whose help the work would have been impossible.

Last but not the least, I would like to express my thanks to local people, Mr. Daya Ram Chaudhari, Tilak Bhattarai, and Bipad Ram Chaudhari (boatman) for their selfless help during field work.

\section{References}

Godwin-Austen, H.. H. 1910. Land and Freshwater Mollusca of India including South Arabia, Baluchistan, Afghanistan, Kashmir, Nepal, Burma, Pegu, Tenasserim, Malay Peninsula, Ceylon and other islands of the Indian Ocean.Suppl.To Theobald and Hanley's conchologia Indica, 2,pl. XI, London.

Pfeiffer, M., S. Sharma and B. M. Dahal 1999. Age and population structure of Freshwater Mussel in the Lowland Rivers of Nepal. Proc. of III Nat. Conf. on Sc. and Tech. pp. 1371-1377.

Preston, H. B. 1915. The Fauna of British India including Ceylon and Burma. Mollusca (Freshwater Gastropoda and Pelecypoda). Taylor and Francis, London, pp.i-xi+ 244.

Subba Rao, N. V. 1989. Handbook of Freshwater Molluscs of India. Publ. Zoological Survey of India, Calcutta.

Subba, B. R. and T. K. Ghosh 2000. Some freshwater molluscs from eastern and central Nepal, J.Bomb. Nat.His.Soc.97 (3): 452-455.

Subba, B. R. and T. K. Ghosh 2001. Land molluscs from eastem and central Nepal.J.Bomb. Nat. Hist. Soc.97 (4): 58-61

Subba, B. R. and M. R. Pandey 2002. Molluscan diversity of Jhapa district. A report to Royal Nepal Academy of Science and Technology, Kathmandu, Nepal.

Tonapi, G. T. 1980. Freshwater animals of India (An Ecological Approach). Oxford and IBH Publ. Co. New Delhi. 